
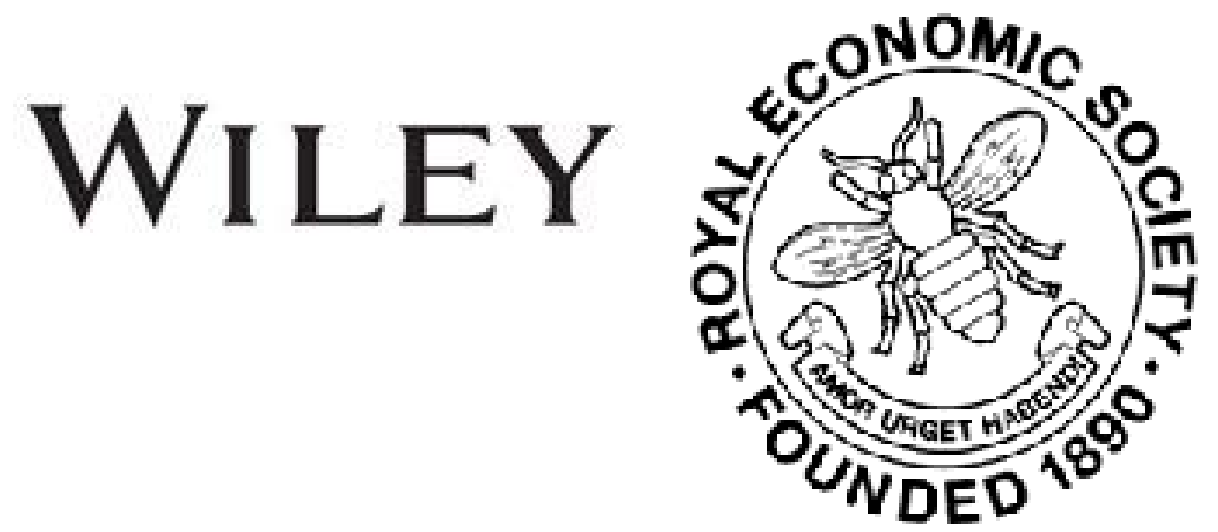

The Report of the Committee on Indian Currency

Author(s): F. C. H.

Source: The Economic Journal, Vol. 8, No. 32 (Dec., 1898), pp. 568-572

Published by: Wiley on behalf of the Royal Economic Society

Stable URL: http://www.jstor.org/stable/2957106

Accessed: 25-06-2016 03:47 UTC

Your use of the JSTOR archive indicates your acceptance of the Terms \& Conditions of Use, available at

http://about.jstor.org/terms

JSTOR is a not-for-profit service that helps scholars, researchers, and students discover, use, and build upon a wide range of content in a trusted digital archive. We use information technology and tools to increase productivity and facilitate new forms of scholarship. For more information about JSTOR, please contact support@jstor.org.

Wiley, Royal Economic Society are collaborating with JSTOR to digitize, preserve and extend access to The Economic Journal 
and Wales, and allows Board of Guardians, subject to the consent of the Local Government Board, to contribute a sum not to exceed $£ 5$ per annum to the Association, and to pay the expenses of two delegates to attend the Association. This Act follows the example already set in the case of District and County Councils ; and the co-operation and uniformity of policy which combined discussion at the central association will tend to secure, is nowhere more necessary than in the case of Boards of Guardians.

IX. The Benefices Act (c. 48) deals with certain well recognised abuses in the exercise by a patron of his advowson or right of patronage, i.e., the right to present a fit clergyman to the bishop as each vacancy arises. With a view to prevent clergymen owners buying livings so as to present themselves, certain restrictions are placed on the free sale of livings. Sales of next presentations are forbidden, all sales must be registered in the Diocesan Registry within a month, and sales by auction of an advowson, save when held in conjunction with a manor, are forbidden. Further, in order to penalise purchasers of advowsons where the incumbent is old, with a view to speedy occupancy, the bishop may refuse to institute a clergyman if at the date of the vacancy not more than one year has elapsed since the last transfer. These restrictions on the right of property seem entirely justified under the special circumstances.

Lastly, one measure of considerable social importance must be mentioned :-

X. The Vaccination Act (c. 49), based on the recommendations of Lord Herschell's Commission of 1896, practically abolishes compulsory vaccination (which has existed since 1853), though nominally leaving it undisturbed. Many Boards of Guardians have long refused to enforce the Act, and now a parent cannot be convicted more than onc e for refusal to have his child vaccinated (sec. 3). Further, if within four months from the birth of the child he satisfies two justices or a stipendiary magistrate that he conscientiously believes that vaccination would be prejudicial to the child's health, he shall not be liable to any penalty. At the same time every inducement is offered to overcome reasonable objections: the period of vaccination is extended from three months to six from birth, the public vaccinator must on parents' request visit the child's home, and glycerinated calf lymph is to be substituted for child lymph, so as to put a stop to the transmission of merely human diseases.

Montague Barlow

\section{The Report of the Committee on Indian Currency}

Iт must be admitted that the minutes of the evidence taken before the Indian Currency Committee are disappointing reading. When the Government decided to submit the Indian proposals to a committee of gentlemen possessing (with two exceptions) no expert knowledge of the 
subject this was inevitable. It may be that it was wise to obtain a judgment from able officials and good men of business rather than from persons committed by their studies, or writings, or speeches, to well-known views upon currency questions. But the result of this decision is to deprive the evidence of much scientific interest. Mr. Ralli, the head of the largest export business in the world, and Sir F. F. Adams, C.I.E., reiteratethose views of the influence of exchange upon the export trade of India which were well exposed by Professor Marshall upon the Gold and Silver Commission. The latter expresses the opinion that " the cheaper India gets her currency the better," and would view a gradual fall of the rupee to sixpence with equanimity and satisfaction. Similarly the former, while refusing to argue the advantages of a rupee worth one penny from dislike of an " academic discussion," can place no limit to the point to which the rupee could fall with advantage to the people of India. Prof. Marshall has clearly shown that a fall in the value of the rupee cannot of itself permanently stimulate the export trade, for the fall " must almost instantaneously accommodate itself to the ratio which gold prices bear to 'silver prices." Moreover, if a fall did stimulate the export trade, where is the advantage? Unless an equivalent is forthcoming India would be giving the additional goods for nothing. So far indeed from the advantage of foreign trade lying in its exports the exact reverse is nearer the truth. It is, or should be, the object of a nation from a business point of view to get as much for as little as possible.

Much evidence is recorded in the interest of tea, which is also strongly represented by a member of the committee. With them it is a subject which, as has been wittily remarked, "does not cheer but inebriates." The plain truth is that this industry has been found to be most remunerative of late years. China has been driven out of the market by the stronger teas of India and Ceylon. The profits earned in the industry have led to a large production, but hitherto the lowering of price due to supply overtaking demand, had occasioned no loss to the grower owing to the fall in the exchange. Loss, however, due to over production could not be long delayed. The rise in the exchange has hastened the crisis, and the prospects of those interested are not at present bright.

To turn to the evidence directly affecting the Indian proposals it is clear that they meet with little support. There is a chorus of disapproval of the scheme to melt rupees. It is worth while to pause and examine the reasonableness of this consensus of opinion. Let us assume that it is agreed to change India's standard to gold. This can be attempted either at the rate of the day, or above it, or below it. The first necessary step is to close the mints to silver. Directly this is done the standard is scientifically exactly similar to inconvertible paper. In other words, the standard is the quantity of the currency in circulation. Now $(a)$, if the intention is to take a ratio lower than the market rate of the day there is no difficulty, for if the currency continues 
at a higher value than gold, this means there is too little of it, and it is merely necessary to mint enough on Government account to bring its value down to the gold par:

(b) if the intention is to take the market rate, then it is sufficient to announce the intention. In this case if the currency rises above the gold par, then, as stated above, a Government mintage of silver solves this difficulty. The real danger, however, is that it may fall below it. As this occurs in the third case it is there dealt with :

(c) if the intention is to take a rate higher than the market rate, then this means that there is more ${ }^{1}$ currency than is required to keep this par. It must, therefore, be reduced. This can be done by leaving the excess quantity to be absorbed by time, or by suddenly recalling a quantity from circulation. There is no other and no royal road to success. The borrowing of large sums in gold will not of itself effect the purpose. The Government of India has hitherto apparently adopted this third course, and has remained inactive for five years in the hope that the rupee would, by absorption, reach $1 s .4 d$. It has now nearly reached that par, and the Government propose to declare its determination to make that rate permanent and effective by melting rupees if necessary.

Sound criticism of the steps proposed by the Indian Government, if the above analysis of the position be correct, must select two main points of attack. It may be objected, firstly, that the attempt to force a valuation upon the silver currency higher than that obtaining at the time embarrasses her trade, and secondly, that an attempt to do so per saltum is a fortiori objectionable. As has already been indicated it has not, and, in my judgment, cannot be, shown that Indian trade gains permanently by a falling or a low exchange. The force, therefore, of this criticism, if any, lies in the effect upon the money market of any (and a fortiori a sudden) attempt to raise the value of an inconvertible currency by restriction. This effect has been much underrated by the Indian Government, and by the commercial community of that country until it was actually felt. It is so little understood that perhaps I may be pardoned by dwelling upon it and borrowing again largely from Marshall's evidence already quoted, which is still, though a decade old, the locus classicus upon this point. In a primitive community, where there is no paper money and little credit, no one would deny the effect upon prices should a Government take brutally from its subjects a large part of the currency in their possession. Yet the result upon prices of

3 The word "redundancy" has often been the source of confusion in the course of the evidence. In the case of an inconvertible currency redundancy is merely an expression relative to the par desired. If $£ 1$ bank-notes, when inconvertible, were worth only $15 s$., then they would be redundant until the quantity recalled was sufficient to bring them to par. So if rupees are worth $1 s .3 d$., they are redundant until reduced to a quantity sufficient to bring them to a desired par of $1 s$. $4 d$. Mr. Ralli, quoting Mr. Cassell, says the rupee cannot be redundant, because, if so, it would be exported. I do not know what Mr. Cassell thinks he would obtain by selling inconvertible paper in a country where it is not current! 
withdrawing part of the currency in a civilised country is similar, though its action is lessened by the existence of other instruments of exchange such as paper and credit. But the modus operandi is not so. simple. When mints are open the banks can import silver, have it coined, and then loan the resultant rupees, and even more, for each accession of hard cash enhances the superstructure of credit. erected upon it. More credit being available business increases, industries and trade are stimulated, and prices rise. Prices having risen they are sustained, because ex hypothesi the currency has been enlarged. Now contrariwise the reverse has been taking place: banks have been unable to import silver as currency, credit has hardened, trade has been embarrassed and prices fall. Prices having fallen they remain low, for the currency has decreased. A word of caution is here necessary. It is not meant that the permanent rate of interest depends on a large or a small volume of currency. On the contrary it depends on the field of employment and the profitableness of industry. All that these currency changes do is to act by the way of the discount market, which is the medium under modern conditions by which prices are altered by a change in the volume of currency. In other words, a high rate of discount is temporarily heightened, or a falling rate prevented temporarily from falling further, by a restriction of the currency. Indian commerce did not realise this, and in consequence not merely did not foresee the effect of restriction but now that it is taking place blames restriction for the whole evil instead of for a small part of it.

As a matter of practical statesmanship, therefore, I have always thought it a grave mistake to attempt to introduce a rate of exchange materially higher than the rate of the day.

The question, however, now before the committee is, what should now be done? The rupee is now worth about $1 s .4 d$., and if there was a good prospect of this rate continuing, there would be little difficulty in the situation. There are, however, grounds for doubting that the rupee will, unassisted, remain at its present level. When the mints closed the rate was 1 s. $2 \frac{3}{8} d$. I do not think the closing of the mint in 1893 has yet raised the value of the rupee by restriction to $1 s$. $4 d$. The famine has probably brought some rupees from hoards. A certain quantity also reappeared after the closure. Good crops have held the rupee up by swelling the volume of exports. The Secretary of State has supported the exchanges by not drawing fully his requirements and by borrowing heavily in gold. I should not be surprised, other things being equal, if the rupee relapsed to $1 s$. $3 \frac{1}{4} d$. when the busy season is over.

To return then to the question, what should be done? Clearly Government cannot announce the rate of $1 s$. $3 d$. whilst the rupee is one penny higher.

Moreover the public think (wrongly-but still the impression exists) that Government is committed to a rate of $1 s .4 d$. On the whole, therefore, the wisest course seems to be to try and acquire a stock of gold quietly (possibly in the way I suggested in the June number) and to 
prevent any extreme pressure in the money market by lending the balances of Government to the banks in the winter and spring. It also seems advisable that a declaration be made of the firm resolve of Government to establish the rate of $1 s .4 d .^{1}$ and to ultimately introduce the sovereign as the standard and currency of the country.

There appears to be a considerable probability of help coming in our Indian difficulties from another quarter. There are indications that the increased and increasing output of gold will cheapen it and bring it down to the inconvertible rupee, and we have, what is the most hopeful feature in the situation, evidence from Lord Rothschild that personally he does " not dread the efflux of gold . . . . if the Indian Government does not buy somebody else does." Hitherto the great stumbling block to a change in the Indian standard has been the fear of the City that Europe could not spare the gold.

F. C. H.

\section{Economic Aspects of the Liquor Problem. 12th Annual Report of the Commissioner of Labour, U.S.A.}

THE Report on the Economic Aspects of the Liquor Problem which has lately been issued by the Commissioner of Labour, U.S.A., is of a very exhaustive character. The subjects dealt with include the production and consumption of liquors; the revenue derived from the manufacture and traffic; the laws regulating the collection of revenue; and the experience and practice of employers in relation to the use of intoxicants; and much interesting information has been collected and many valuable statistics.

The production of liquors is naturally the first subject for consideration, and figures are given showing the number of breweries and distilleries in operation and the amount of their production between the years 1880 and 1896. With regard to distilleries the number fluctuates in a very surprising and sudden manner, and the changes have no apparent connection with the amount of spirits produced. For instance, to take the last three years for which particulars are given, in 1894 there were 5,148 distilleries at work; a number which sank to 2,429 in 1895 and rose equally abruptly to 6,187 in 1896 .

With regard to breweries, the tendency in modern trading for the small concerns to disappear, while the large ones do a bigger and bigger business, appears to prevail in the brewing trade. Since 1880 there has been an almost continuous diminution in the number of breweries, which has sunk from 2,741 to 1,866. The production of distilled

1 Several people, including witnesses, have objected to the declaration of a rate, saying it leads to its evasion. But a rate must be adopted, and the fallacy of this argument is well exposed by Sir David Barbour in the course of the evidence. Merchants who hold off to avoid the maximum must, if they continue business, operate some time. Their action if they operate when exchange is low, operates to raise a low exchange, and therefore raises the mean rate. 